First Peoples Child \& Family Review

An Interdisciplinary Journal Honouring the Voices, Perspectives, and Knowledges of

First Peoples through Research, Critical Analyses, Stories, Standpoints and Media

Reviews

\title{
Foreword
}

\section{Margaret Kovach}

Volume 4, Number 2, 2009

URI: https://id.erudit.org/iderudit/1069323ar

DOI: https://doi.org/10.7202/1069323ar

See table of contents

Publisher(s)

First Nations Child and Family Caring Society of Canada

ISSN

1708-489X (print)

2293-6610 (digital)

Explore this journal

Cite this document

Kovach, M. (2009). Foreword. First Peoples Child \& Family Review, 4(2), 4-4.

https://doi.org/10.7202/1069323ar viewed online.

https://apropos.erudit.org/en/users/policy-on-use/ 


\title{
Foreword:
}

\author{
Margaret Kovach, Ph.D. \\ Editorial Board Member of the First Peoples Child \& Family Review
}

Tanisi. In writing the forward for this edition of the First Peoples Child \& Family Review, I am impressed by the interdisciplinary nature of the contributions. Over the past several months I have been reflecting upon the importance of interdisplinarity in serving Indigenous children and families. As a faculty member at the College of Education, University of Saskatchewan having transitioned three years ago from a teaching position at the School of Social Work, University of Victoria, cross disciplinary engagement is never far from mind. However, on a broader level there have been two recent events that have re-enforced my belief in a relational interdisciplinarity as a best practice approach. Earlier this fall, I attended an Indigenous scholar's workshop - a pre-symposium gathering of the Prairie Child Welfare Consortium held Winnipeg, Manitoba. The gathering attracted attendees from the social work practice and academic community who, through a series of discussion circles, identified pertinent areas where practioners and academics could work together to further support Indigenous families and communities. The importance of cross disciplinary collaboration between service providers was identified. Sitting in the discussion circle, I was able to reflect again upon the disciplines of social work and education. I know that for many Canadian Indigenous children involved in the child welfare system, social workers and teachers are a daily constant. Yet, the extent to which these two groups work together and the nature of that particular interdisciplinary relationship is unclear and largely undocumented in research. Creating opportunities for cross disciplinary service providers from social work, health, education, justice (to name a few) to develop collaborative relationships is important because an interdisciplinary approach holds within it the potential to improve practice and better serve Indigenous children and families.

From a larger advocacy perspective, the criticality of understanding structural barriers experienced by First Nations peoples across service sectors can never be more important. On November 23, 2009 I listened to a powerful $\mathrm{CBC}$ interview with Cindy Blackstock and Carolyn Buffalo. The focus of the interview was on the Canadian Human Rights Tribunal set to hear evidence and determine whether or not the Canadian government has discriminated against First Nations children. On behalf of First Nations in Canada, The Assembly of First Nations and the First Nations Child and Family Caring Society of Canada have lodged a complaint with the Canadian Human Rights Tribunal asserting a violation of the equality provision of the Canadian Charter of Rights and Freedoms. While a focus of the Tribunal hearing relates to First Nations child and family funding, the interview highlighted the cross disciplinary nature of the problem. In relating her experience, Carolyn Buffalo spoke about her family's personal experience of encountering barriers when attempting to access special needs funding to enrol her child in the provincial school system. First Nations people experience structural barriers across disciplinary boundaries. The more service providers are aware of cross disciplinary challenges, the better equipped we are to join together to create overall change.

Providing a forum for interdisciplinary information sharing is central to facilitate a relational interdisciplinary approach. I am so very pleased to write the forward for this edition of The First Peoples Child\& Family Review. It is a journal that upholds the value of all my relations in serving Indigenous peoples. Ekosi.
Marget Kovach, Assistant Professor.

Department of Educational Foundations and Department of Educational Administration College of Education, University of Saskatchewan 